\title{
PROPRIEDADE E POSSE: UMA RELEITURA DOS ANCESTRAIS INSTITUTOS'
}

\author{
Giselda Maria Fernandes Novaes Hironaka \\ Professora Associada do Departamento de Direito Civil \\ da Faculdade de Direito da Universidade de São Paulo \\ Silmara Juny de Abreu Chinelato \\ Professora Associada do Departamento de Direito Civil \\ da Faculdade de Direito da Universidade de São Paulo
}

Resumo:

Conceito, conteúdo e limitações da propriedade são objetos de estudo histórico, de Roma ao Direito contemporâneo. As várias teorias sobre a posse e sua importância na atualidade, como direito autônomo, bem como o conceito plurívoco de propriedade são temas analisados para melhor compreender os reflexos na Constituição Federal e no Direito Civil. Considera-se, ainda, a especialidade do Direito Agrário bem como do Direito de Autor.

Abstract:

Concept, contents and property's limitations are object of hystorical study, from Rome to the Contemporany Law. Any theories about possession and its actual importance, as autonomyc law, added to the plural concept of propriety are themes analysed in order to better comprehend the reflexes on Federal Constitution and Civil Law. It still considers the speciallity of Agrarian and Author Law.

Unitermos: posse; propriedade; Direitos Reais; limitações à propriedade; Direito Autoral

"Não pretendo romper com toda uma tradição civilista e proceder a um processo de futurologia, para descrever toda a estrutura civilista, esboçando um novo Direito, como que tirado do nada. Nem me anima uma atitude iconoclasta, com a destruição da ordem jurídica existente

I. Estudos cm homenagem ao Professor Catedrático Josć Carlos Morcira Alves 
e criação de um novus ordo. [...] Tudo o que acontece no mundo, acontece uma só vez. Uma reforma do Direito Civil tem de considerar que ninguém se pode instalar comodamente deitado sobre a ordem estabelecida; e esperar inerte que a justiça lhe caia do céu. [...] O Direito do século XXI forçosamente será diferente do presente, em razão de que o mundo está em permanente mutação um perpetuo mobile - que constantemente terá de absorver o caráter mutante de uma sociedade em permanente evolução. [...] Tenho sentido que se realiza uma transformação nos conceitos jurídicos, permitindo antever que, sobre o Direito que recebemos de nossos maiores, já se desenham as mudanças, permitindo às novas gerações readquirir a fé e a esperança em novos valores." (Caio Mário da Silva Pereira, Direito Civil: alguns aspectos de sua evolução. Rio de Janeiro: Editora Forense, 2001, in Prefácio, pp. IX e X)

1. Evolução da propriedade sob o enfoque de uma breve retrospectiva histórica, em Roma e na Idade Média: o conteúdo e as limitações ao direito de propriedade. A Revolução Francesa e os ideais de Napoleão.

Um exame retrospectivo histórico, ainda que brevíssimo, se torna essencial para a completude da intenção de revisar os ancestrais institutos sob uma ótica mais consentânea com a realidade, sob as luzes deste arquétipo, costumeiramente denominado de pós-modernismo, ${ }^{2}$ e que exige uma distinta atenção do estudioso do Direito, do intérprete das normas à face dos fatos da vida contemporânea e do aplicador das leis.

2. Scgundo Antonio Junqucira de Azcvedo ("O Dircito pós-moderno c a codificação". Revista da Faculdade de Direito da Universidade de São Paulo, v. 94, pp. 3-11, 1999) as caracteristicas do Dircito pós-moderno são três: a) crisc da razão; b) hipercomplexidade ou multiplicidade de fontes do Dircito, matcriais $\mathrm{c}$ formais; $\mathrm{c}$ ) interação. Quanto à ultima caracteristica, cnfatiza o autor a nccessidade de sc codificar de modo interativo, participativo, democrático, como ocorrcu com o recente Código Civil da Holanda, de 1992, cujas cinqüenta c duas teses fundamentais foram apresentadas, para discussão, aos cstamentos interessados. Para Erik Jayme ("Identitć culturclle ct intégration: Le droit international privć postmoderne" Cours Général de Droit International Privé, Recueil des Cours. Académie de Droit International, t. 251. The Haguc - Boston - London: Martinus Nijhoff Publishcrs, 1996, p. $246 \mathrm{c}$ ss) a cultura jurídica pósmoderna ć caracterizada por quatro fenômenos: a) pluralismo - de fontes legislativas $\mathrm{c}$ de sujcitos a proteger, b) a comunicação, c) a narrativa c d) o retorno aos sentimentos (retour des sentiments). 
Segundo Moreira Alves, o direito de propriedade não foi definido no Direito Romano.

Na Idade Média, juristas o fizeram fundamentando-se em alguns textos que, no entanto, não se referiam à propriedade. Com base em um rescrito de Constantino (C.IV, 35, 21) relativo à gestão de negócios, os juristas definiram o proprietário como suae rei moderator et arbiter (regente e árbitro de sua coisa). De fragmento do Digesto (D.5,3, 25,11) sobre o possuidor de boa-fé, deduziram que a propriedade seria o ius utendi et abutendi re sua (direito de usar e de abusar de sua coisa). ${ }^{3}$

Do Digesto 1,5,4, pr., em que se define a liberdade, resultou a aplicação desse conceito à propriedade que, então, seria a "faculdade natural de se fazer o que se quiser sobre a coisa, exceto aquilo que é vedado pela força ou pelo direito" . ${ }^{4}$

Acentua Moreira Alves que, ao longo de uma dezena de séculos, o Direito Romano sofreu mudanças, repercutindo também no conteúdo do direito de propriedade que se alarga ou se reduz, tendo em vista não-só o regime político, como também as exigências econômico-sociais. Mesmo o conceito de Bonfante bastante difundido, peca pela incompletude: "propriedade é a senhoria mais geral sobre a coisa, seja em ato, seja pelo menos em potência" ' Como observa Volterra, este conceito reflete só a propriedade romana primitiva (soberania do pater familias sobre a coisa), mas não se aplica exatamente à propriedade como se apresenta nos direitos clássico e pós-clássico.

Para Moreira Alves, parece ser correta a afirmação de Carlo Longo, no sentido de que a distinção entre o direito de propriedade e os outros direitos reais (iura in re aliena) é a circunstância de ser ele o direito real de conteúdo mais amplo, e o único autônomo. ${ }^{6}$

No periodo pré-classico, os romanos só conheceram uma espécie de propriedade: a propriedade quiritária (ex iure quiritium), a qual era incumbida tão apenas aos cidadãos romanos, ou a um latino ou peregrino que tivesse o ius commercii. Seu objeto era a coisa móvel ou imóvel. Se imóvel, só configurava propriedade quiritária, se situado na Itália ou nas províncias onde se estendera o ius italicum.

3. Josć Carlos Morcira Alves. Direito Romano, v. I. 10a cd. Rio de Janciro: Forensc, 1995, p. 270 c ss.

4. O texto original, que se referc à libcrdade, foi assim traduzido por Hćlcio Macicl França Madcira, na obra Digesto de Justiniano, livro I. $2^{\text {a }} \mathrm{cd}$. São Paulo: RT, 2000, p. 55: "A liberdade é a faculdade natural de fazer o que a cada um apraz, a não ser que isto seja proibido pela força ou pelo direito".

5. Reproduzido cm suas Istituzioni di Diritto Romano, X. cdizionc, § 80, p. 249.

6. Morcira Alves se referc, na página 282, à obra de Carlo Longo, Corso di Diritto Romano - Le cose - La proprietà e i suoi modi di acquisto, p. 74. 
No Direito clássico encontramos, ao lado da propriedade quiritária, três situações análogas: propriedade bonitária ou pretoriana; propriedade provincial e propriedade peregrina. Em breve síntese, releiam-se as suas características fundamentais:

Propriedade bonitária ou pretoriana - surgiu quando o pretor passou a proteger a pessoa que, tendo comprado uma res mancipi (móvel), recebia-a do vendedor por meio da simples traditio e não pela forma solene da propriedade quiritária, a mancipatio ou a in iure cessio. Assim, a traditio não transferia a propriedade ao comprador. $\mathrm{O}$ vendedor continuava a ter a propriedade quiritária sobre a coisa, podendo reivindicá-la do comprador, situação iníqua.

Propriedade provincial - referia-se a imóveis que estavam situados nas províncias às quais não tinha sido estendido o ius italicum. Os particulares - cidadãos romanos ou-não - só podiam ter a posse, pagando stipendium para o povo romano, se provincia senatorial, ou tributum, para o príncipe, se província imperial.

Propriedade peregrina - peregrinos que não tivessem o ius commercii não podiam ter, sobre coisas imóveis ou móveis, a propriedade quiritária. Se comprassem móveis ou imóveis suscetíveis de serem objeto de propriedade quiritária, seriam deles meros possuidores. Uma verdadeira propriedade de fato que foi sendo protegida pelos pretores peregrinos, em Roma, e pelos governadores, nas províncias. Aos peregrinos eram concedidas ações reais análogas às que protegiam a propriedade quiritária. Muitas dessas ações tinham cláusula em que o magistrado ordenava ao juiz que julgasse a questão como se o peregrino fosse cidadão romano (ações fictícias, portanto).

No período pós-clássico, essas diferentes espécies de propriedade vão desaparecendo até que, ao tempo de Justiniano, só se encontrará uma única propriedade. Moreira Alves aponta as seguintes características desse modelo, no Direito Justinianeu: a) a propriedade era transferida pela simples traditio (no Direito clássico, a traditio ocorria só na propriedade pretoriana ou bonitária); b) estava sempre sujeita aos impostos (no período clássico, a sujeição só alcançava a propriedade provincial); c) sobre a propriedade pesava uma série de limitações impostas por necessidade da Administração pública (no Direito clássico as limitações se referiam à propriedade provincial).

São várias as causas que deram origem a esta unificação, sendo a principa! a extensão da cidadania a quase todos os habitantes do Império Romano, em 212 d.C., por Caracala, fazendo com que a propriedade peregrina praticamente desaparecesse.

São relevantes, ainda, para o arrolamento das causas, a fusão do ius civile e o ius honorarium e o desaparecimento das formas solenes de transmissão de propriedade, resultando a extinção da propriedade pretoriana. 
Aponte-se, ainda, que a isenção de impostos para a propriedade quiritária deixou de existir com Diocleciano (285 a 305 d.C.). A partir deste momento, o pagamento de impostos por todos não mais significava que o Estado era o proprietário do imóvel e o particular, simples possuidor.

Assim alinhavado, em breves esquemas historiográficos, o percurso romano da propriedade, é necessário enfatizar, mais uma vez, que o conceito de propriedade foi construído na Idade Média e não no Direito Romano, conforme já perfeitamente demonstrado por Moreira Alves. O sentido de "abuti" não parece ser o mesmo sentido de "abusar" senão simplesmente o de "dispor" 7

Quanto às limitações propriedade, foi possivel reconhecê-las por três origens diferentes: por vontade do proprietário (iura in re aliena); por causas naturais e por força de lei. Como exemplo de limitações naturais pode ser mencionado o fato de que o proprietário só pudesse usar o espaço aéreo sobre o imóvel ou seu subsolo, até onde fosse economicamente possível atingir. Tratava-se de limitações impostas pela fragilidade da força humana, considerada nas características daquele tempo.

As mais importantes limitações decorrentes da lei apresentaram-se, no Direito Romano, desde o período pré-clássico, e atingiam bens imóveis e bens móveis. Quanto aos imóveis, eram impostas por interesses de particulares - direitos de vizinhança - e por interesse do Estado. Em face dessas limitações, o proprietário deveria abster-se de certos usos da coisa (non facere) ou deveria tolerar que outrem dela se utilizasse (pati).

Moreira Alves analisa, de modo acentuado e esclarecedor, as limitações nos períodos pré-clássico, clássico e pós-clássico. No período pré-clássico, essas limitações encontravam-se na Lei das XII Tábuas. Entre elas, por exemplo, pode ser citado o fato de o proprietário de um terreno estar obrigado a permitir que os galhos das árvores do vizinho se projetem sobre seu imóvel, até altura determinada, podendo cortá-los caso se projetem abaixo dessa altura limite. Outros exemplos de limitações legais desse período são interessantes de serem descritos, como o fato de o proprietário poder entrar - dia sim, dia não - no imóvel do vizinho para colher frutos caídos de suas árvores; ou o fato de o proprietário estar obrigado a conservar a estrada que confinasse com seu imóvel, sob pena de ter de permitir a passagem - inclusive de animais - por seu terreno; ou, ainda, o fato de estar obrigado, o proprietário, a permitir a passagem para o sepulcro de alguém, se este fosse o único caminho. (Digesto 11, 7,12, pr.). 
Por outra parte, e ainda como descrição legal de limitações ao direito de propriedade, anote-se que as Constituições imperiais estabeleceram, para as cidades grandes, a altura máxima dos prédios. Em Cícero, De legibus, encontra-se, por exemplo, a proibição de se sepultar mortos em imóvel, dentro de uma cidade; e, fora dela, também incidiu a proibição, até uma distância mínima de qualquer edifício. A Constituição de Antonino Pio (Institutas de Gaio, I, 53), por sua vez, estabeleceu que o dono de um escravo, se o maltratasse, estaria obrigado a vendê-lo.

Já no período pós-clássico, as limitações ao direito de propriedade aumentaram de modo significativo, restando ao proprietário obrigado, por exemplo, a permitir a escavação de minas, em seu terreno, por terceiros, recebendo $10 \%$ do valor, com igual percentagem ao Estado. Aumentaram também, nesse período, as limitações às construções, quanto à distância entre uma e outra, e quanto à altura máxima.

Como formidável prenúncio à noção de funcionalidade social da propriedade, registrou-se, nesse tempo, penalidade para o proprietário que não cultivasse o seu terreno, prescrevendo que ele perderia o seu direito de propriedade em favor de quem o cultivasse por mais de dois anos. Nessa esteira de preceitos legais prenunciadores de limitações que podem ter sido o embrião de prescrições restritivas atuais, é curioso anotar, também, o que proibia o proprietário de levantar construção de modo a impedir que o vento atingisse o terreno do vizinho, proibição esta que destacou, à evidência, a rejeição romana, nesse período, ao uso anti-social da propriedade.

Quanto à desapropriação e uso anormal da propriedade, notadamente quanto ao direito de vizinhança - imissão de fumaça, calor, ondas sonoras - 0 assunto já se mostrou mais polemizado, pois não há fonte segura que ateste essas limitações. Moreira Alves informa que na Idade Média surgiu a proibição de atos emulativos - ad aemulationem - que visem apenas a prejudicar os vizinhos. ${ }^{8}$

O romanista Andrea Di Porto escreveu um interessante ensaio sobre a proteção do meio ambiente no Direito Romano, inclusive no que diz respeito à defesa e proteção dos rios. Assim o autor resume seu pensamento: "o papel do cidadão na tutela do ambiente merece destaque já na antiguidade quando se verifica a conexão entre desenvolvimento e poluição. O problema da adoção de formas de tutela da salubritas se apresenta efetivamente no mundo romano. Vemos, por conseguinte, que $o$ quadro das formas de tutela, emergente das fontes, apresenta-se orgânico e rico de

8. As limitaçõcs ao dircito de propricdade encontram-sc nas páginas 285-8 da obra Direito Romano, v. $1,10^{a}$ cd., 1995. 
instrumentos eficazes, vis-à-vis o forte desenvolvimento econômico-social vinculado ao grande desenvolvimento urbanístico de Roma (III séc. a. C)" 9

Na Idade Média, novas concepções foram deflagradas e alterou-se profundamente a feição do direito de propriedade, infelizmente não para melhor, circunstância em que a propriedade passou a ser considerada de modo desmembrado, dividindo-se em domínio direto e domínio útil, este último endereçado ao vassalo, subserviente do titular do domínio direto, seu senhor e suserano. ${ }^{10}$

Ocorreu, então, a introdução de uma hierarquia oriunda do Direito Público na técnica privatística do Direito das Coisas, admitindo uma superposição de domínios de diferentes densidades. A valorização do solo e a estreita dependência entre o poder político e a propriedade criaram uma identificação entre a soberania e a propriedade."

Todos esses privilégios da realeza e também do clero, cuja duração se prolongou por mais de dez séculos, foram, afinal, sufocados pela Revolução Francesa, no século XVIII. A Revolução teve por meta a extinção do servilismo que impregnou o regime anterior, trazendo a libertação das instituições e a humanização dos direitos.

Dentre tais direitos, destacou-se, sem dúvida, o direito de propriedade, já que a Revolução, numa palavra, libertara o solo. ${ }^{12} \mathrm{E}$ o grande monumento legislativo deste momento histórico foi o Código francês (1804). No entanto, sabe-se, não possuiu este Código, destarte a sua grandiosa novidade e prestígio, o carisma de ser eterno, como supôs o próprio Napoleão, quando vaticinou: 'Minha glória não é ter vencido quarenta batalhas; o que nada ofuscará, o que viverá eternamente, será o meu Código Civil ${ }^{13}$

Enganou-se o imperador, certamente, pois os atributos da imutabilidade e da eternização não podiam - como não podem - ser imputados a nenhuma espécie ou tentativa de estratificação dos fatos da vida dos homens, exatamente porque os fatos mudam e torna-se impossivel suportar o descompasso entre a norma, pensada imutável, e a dinâmica própria da vida.

9. "O papel do cidadão na tutcla do ambiente". Estudos Juridicos. Universidade do Vale do Rio dos Sinos. V. 23, n. 59, sct/out 1990, pp. 79-83. Trabalho apresentado no VI Congresso Latino-Amcricano de Dircito Romano, Civil c Comparado, realizado no Rio de Janciro, $\mathrm{cm} 1990 \mathrm{c}$ faz parte de pesquisa maior claborada pclo autor. Traduçào de Myriam Bcnarrós.

10. Gisclda M. Fernandes Novacs Hironaka, "Enfitcuse". Direito Civil - Estudos. Bclo Horizontc: Del Rey, 2000, pp. 185-193.

11. Emilio Gischkow. Principios de Direito Agrário. São Paulo: Saraiva, 1988, p. 100.

12. Orlando Gomes. A crise do Direito. São Paulo: Ed. Max Limonad, 1955, p. 118.

13. Gisclda M. Fernandes Novacs Hironaka. "Função Social do Contrato". Direito Civil-Estuclos. Bclo Horizontc: Del Rcy, 2000, pp. 101-117. 
Não se eternizou o Código, não se eternizaram os valores individualistas que emergiram da lógica da Revolução. Mas, ao contrário, transformaram-se os homens, alteraram-se os fatos, sociabilizou-se a sociedade, instalaram-se os chamados direitos de segunda geração ${ }^{14}$ ou direitos sociais, que insere o sujeito de direito na completude social, em superação ao modelo que simplesmente imputa a cada homem de per se considerado, e a todos, a um só tempo, o status da igualdade formal perante a lei, que marca e caracteriza a teoria individualista da era moderna.

Destes direitos sociais destaca-se o reconhecimento das liberdades políticas e das liberdades sociais que tiveram, como matriz ou fonte, exatamente a trajetória dos movimentos chamados sociais, de trabalhadores sem salário e sem terra, de desvalidos sem assistência, de crianças e idosos sem benefícios, de pobres sem a atribuição da condição de cidadãos.

É Norberto Bobbio ${ }^{15}$ quem elenca, a partir desta alteração de paradigmas sociais ou de status sociais, o nascedouro destes novos direitos, referindo-se à promulgação de textos legislativos como a Convenção sobre os Direitos Políticos da Mulher (1952), a Declaração dos Direitos da Criança (1959), a Declaração dos Direitos do Deficiente Físico (1975) ou a Declaração dos Direitos do Ancião na Assembléia de Viena (1982).

Para tanto quanto interessa a este estudo, no mesmo diapasão, reformulouse o paradigma da propriedade, para incorporar o atributo da função social que the passou a ser inerente.

2. A doutrina da função social. A filosofia tomista e as encíclicas papais. Leon Duguit. A Constituição de Weimar. O ordenamento constitucional brasileiro.

A idéia de função social - sabe-se - não era nova, não foi criada neste momento de transformação e de socialização do direito. Por isso, quando ocorre a referência a nascer ou a novo direito, na verdade só se está produzindo uma espécie de reflorescimento de idéias já bem antigas, pinçadas à Bíblia, ao Direito Romano ou aos grandes filósofos do passado.

A doutrina social da Igreja católica teve seu ponto alto registrado por São Tomás de Aquino, o Doutor Angélico, ${ }^{16}$ que vislumbrou na propriedade o seu

14. Cf. Norberto Bobbio. A Era dos Direitos. trad. Carlos Nelson Coutinho. Rio de Janciro: Ed. Campus, 1992, passim.

15. Norbcrto Bobbio. idem, p. 69.

16. Gisclda M. Fcrnandes Novacs Hironaka, "Função Social do Contrato", cit., pp. 102-103. 
traço original de Direito Natural que, paulatinamente, vai se modificando e, de modo artificial, admite a apropriação pelo homem das parcelas do que antes a todos pertencia, coletivamente. Por isso, em cada época - como escreve Luiz Edson Fachin ${ }^{17}-a$ propriedade constituiu-se de contornos diversos, conforme as relações sociais $e$ econômicas de cada momento; o grau de complexidade hoje alcançado pelo instituto da propriedade deriva indisfarçavelmente do grau de complexidade das relações sociais.

Este modo artificial de transmudação do Direito Natural, segundo a concepção tomista, traduzia exatamente a norma positiva, que conferiu os bens a certas titularidades, regulamentou a sua divisão, a sua transmissão e a sua proteção.

Importantes encíclicas papais derivaram desta concepção filosófica e entre elas a mais importante a Rerum Novarum (1891), de Leão XIII, que reconheceu à propriedade privada sua função social, sua função de utilidade comum a todos, deixando a salvo, contudo, a iniciativa privada, garantindo, desta forma, a liberdade e a dignidade humanas. ${ }^{18}$

Além desta famosa encíclica, outras merecem destaque, ladeando-se a preciosas mensagens papais, constituindo, todas, o arcabouço histórico da evolução do direito de propriedade, pelo prisma da doutrina social da Igreja. Entre elas: a encíclica Quadragesimo Anno (1931), de Pio XI, a Mater et Magistra (1961), de João XXIII e, ainda, a Populorum Progressio (...) de Paulo VI, esta última reproduzindo a famosa idéia tomista de que o supérfluo dos ricos é o necessário para os pobres. Entre as mensagens papais, merecem especial registro a La Solemita (1941) e a Oggi (1944).

A visão da Igreja é nitidamente funcionalista, como se verifica pelos registros de tão especiais e ilustrativos documentos papais, e construiu a base do pensamento católico acerca da propriedade. A influência, pois, da Igreja, na concepção evolutiva da propriedade é absolutamente marcante, registrando-se nos momentos críticos da sociedade humana e sua histórica, buscando, principalmente, estabelecer limitações ao absolutismo e ao individualismo e até às arremetidas do Estado sobre a propriedade privada em nome do interesse público. ${ }^{19}$

Posição assemelhada a esta - ao menos no que diz respeito ao reconhecimento de um função social associada à concepção da propriedade - já havia

17. Luiz Edson Fachin. Função Social da Posse e da Propriedade Contemporânea. Porto Alcgre: Scrgio Antonio Fabris Editor, 1988, p. 18.

18. Gisclda M. Femandes Novacs Hironaka, "Função Social do Contrato", cit, p. 103.

19. Carlos Albcrto Dabus Maluf. Limitações ao Direito de Propriedade. São Paulo: Editora Saraiva, 1997, pp. 56-57. 
sido igualmente defendida por Leon Duguit, autor francês de arrojada tese acerca do assunto, conforme lançou os registros em sua famosíssima obra Transformações Gerais do Direito Privado, desde o Código de Napoleão (1912), cuja síntese poderia ser refletida pela afirmação do polêmico pensador a respeito de que a propriedade não é, pois, $o$ direito subjetivo do proprietário: é a função social do detentor da riqueza. ${ }^{20}$

A teoria de negação dos direitos subjetivos de Duguit, como se afere, baseou-se na concepção de propriedade - senão como um direito subjetivo - como um dever, evoluindo para a concep̧̧ão do que se convencionou denominar propriedadefunção. Desta forma, entendeu ele que o homem não tinha direitos, mas seria tãosomente um instrumento a serviço da sociedade; vale dizer, por ser membro de uma coletividade, cada um teria obrigações a cumprir, sob o referencial da função social a cada um incumbida e de sorte a que, segundo ele, ninguém possui mais direitos senão aqueles de cumprir com seus deveres. ${ }^{21}$

Com toda a certeza, o grande positivista francês excedeu-se em suas considerações, especialmente ao concluir sua tese que negou a existência de direitos subjetivos. Contudo, têm os autores da contemporaneidade repetido que, se a doutrina de Duguit não foi aceita na sua integridade, suas conclusões, por outro lado, oferecem importantes vertentes acerca do raciocínio filosófico sobre a função social.

Não parece restar mais dúvida, na atualidade, a respeito de que a propriedade não é uma função social, mas que - isso sim - tem uma função social que lhe é inerente, significando que se encontrará o proprietário obrigado a dar uma determinada destinação social aos seus bens, concorrendo, assim, para a harmonização do uso da propriedade privada ao interesse social, mas sem o exagero da coletivização dos bens, modus próprio de outro regime ou sistema político-econômico, de natureza socialista.

De toda a sorte, o que se passa, enfim, é este excepcional e indiscutivelmente real fenômeno que restringe e limita o exercício do direito de

20. Cf. menciona Carlos Alberto Dabus Maluf (Limitações ao Direito de Propriedacle. cit., p. 61-62), reproduzindo o âmago do pensamento de Duguit no seguinte percurso de sua obra: A propriedade é para todo o possuidor de una riqueza o devel; a obrigação, de ordem subjetiva, de empregar a riqueza que possui e manter e aumentar a interdependência social. Todo individwo tem a obrigação de cumprit na sociedade uma certa função em razão direta do lugar que nela ocupa, o possuidor da riqueza, pelo fato mesmo de possui-la, pode realizar un certo trabalho que só ele mesmo pode fazer: Está, pois, obrigado socialmente a realizar esta tarefa e não será protegido socialmente mais do que a cumpra e na medida que a cumpra. A propriedade não é, pois, o direito subjetivo do proprietário: éa função social do detentor dla riqueza.

21. Gisclda M. Fernandes Novacs Hironaka, "Função Social do Contrato", cit., p. 106. 
propriedade, pela faceta de suas diversas faculdades jurídicas, aparando arestas do individualismo tradicional, como diria Caio Mário da Silva Pereira, ${ }^{22}$ e bombardeando, de todos os ângulos, o absolutismo do direito de propriedade [...]. ${ }^{23}$

O espírito mesmo da legitimidade da concepção, a verdadeira mola de admissibilidade e de fundamentação de uma tal funcionalização do direito de propriedade - ou socialização do direito, ou paternalização das instituições, ou humanização das relações jurídicas, como preferem as mais distintas correntes do pensamento filosófico-jurídico da era pós-moderna ou contemporânea - reside, por certo, no fato de que a propriedade individual, dentro nas vestes tradicionais, não conserva o conteúdo ético de assenhoramento que exprime o contexto do artigo 524 do Código Civil [atual caput do artigo 1.228]; não se compraz com as idéias dominantes neste começo de milênio, que o dominus tenha o poder de utilização e gozo da coisa sua, numa tal extensão e profundidade que chegue a sacrificar o direito alheio, ou mais precisamente, o bem-estar de toda a comunidade. ${ }^{24}$

$\mathrm{O}$ reconhecimento de uma nova ordem - acima e além da manière plus absolue de jouir e disposer des choses ${ }^{25}$ - instalou-se, com a superação do princípio pré-revolucionário do laisser faire, laisser passer, com a superação da atribuição de poder absoluto ao titular do direito de propriedade.

A Constituição alemã de Weimar (1919) revelou a síntese perfeita, a expressão mais simples, desta nova concepção de inversão de status de titularidade, ao normatizar, pelo viés do seu artigo 153, que a propriedade obriga. Registro histórico da maior importância, na primeira metade do século passado, esta Carta determinou expressamente que o uso da propriedade deveria se processar à face do interesse geral. Viga mestra da assunção principiológica constitucional da nova ordem, a concepção de Weimar espalhou-se por outras Constituições estrangeiras, que, igualmente, consignaram o importante princípio.

Adverte Clóvis do Couto e Silva que não foi fácil estabelecer seu significado, por duas razões. O Direito Constitucional e o Direito Civil eram considerados territórios autônomos, incomunicáveis, fruto natural da separação entre

22. Caio Mário da Silva Percira. Direito Civil - alguns aspectos de sua evolução. Rio de Janciro: Editora Forcnse, 2001 , p. 70.

23. Caio Mário da Silva Pcrcira. idem, p. 71.

24. Caio Mário da Silva Percira. idem, pp.71-72.

25. Conforme a famosa consagração do artigo 544 do Código Civil francês (1804). 
o Estado e a sociedade própria da concepção liberal. Acresça-se a neutralidade valorativa que definia o Direito Privado. ${ }^{26}$

Observa-se, contudo, não ser esta a diretriz atual, desde fins do segundo milênio quando, então, ganha cada vez mais importância a visão do Direito Civil com base constitucional - por alguns denominado Direito Civil Constitucional - bem como a interpenetração do Direito Civil no Direito Público e do Direito Público no Direito Civil, tema bem tratado por Michele Giorgiani ${ }^{27}$ e, entre nós, por Maria Sylvia Zanella Di Pietro. $^{28}$

Clóvis do Couto e Silva observa ainda que, quando o art. $153 \mathrm{da}$ Constituição de Weimar consagrou o princípio segundo o qual a propriedade obriga, dando expressão a uma idéia ainda sem forma, mas em vigor no mundo social, anotou Martin Wolff que se tratava de um princípio tradicional no Direito germânico.

Para Martin Wolff - e segundo a visão de Clóvis do Couto e Silva - do mencionado princípio resultaria para todo e qualquer direito subjetivo uma dupla obrigação para o titular: o dever de exercer o direito, se for de interesse público e o dever de exercê-lo de modo que satisfaça ao referido interesse público. Escreve o jurista gaúcho: "Acresce, ainda, que o principio a propriedade obriga tem, ademais, o significado de que o patrimônio obriga, para concluir que nesta última fórmula vive, concomitantemente, uma fração do postulado revolucionário da fraternidade. Assim, a concepção moderna da propriedade toma uma outra conotação, e a diversidade dos objetos sobre os quais ela recai passa a exigir uma regulamentação que lhe seja própria, de tudo resultando vários tipos de propriedade. A grande modificação que se operou no Direito brasileiro relacionou-se, como na maioria dos países, com a propriedade agrária e urbana - em última análise, com a Reforma Agrária e urbana" ${ }^{29}$

Entre nós, brasileiros, apenas a partir de 1934 é que a doutrina da função social alcançou o bojo constitucional, desenhando-se os seus primeiros contornos. Não repetiu a posição, a Carta de 1937, regresso prejudicial no arco evolutivo da propriedade brasileira, mormente a fundiária.

26. "O Dircito Civil brasilciro cm perspectiva histórica c visão de futuro". Revista dos Tribunais, 11. 628,1988 . O mesmo cnsaio foi republicado $\mathrm{cm}$ O Direito privado brasileiro na visão de Clóvis do Couto e Silva. Vera Maria Jacob de Fradera (coordenadora). Porto Alegre: Livraria do Advogado Editora, 1997.

27. “O Dircito Privado c as suas atuais frontciras". Revista dos Tribunais, v. 747:35 c ss.

28. Consultc-sc Maria Sylvia Zanclla Di Pictro cm Do Direito privado na Adıninistração Pública. São Paulo: Atlas, 1989.

29. "O Dircito civil brasilciro cm perspectiva histórica c visão de futuro". O Direito Privado brasileiro na visão de Clóvis do Couto e Silva, cit., pp. 11-31. A citação cncontra-sc na p. 22, in fine, c 23. 
Mas o tema foi reabsorvido pela Constituição subseqüente (1946) que, no art. 147, condicionou o uso da propriedade ao bem-estar social. Lembra Gustavo Tepedino que a preocupação da Constituição Federal de 1946, com a função social da propriedade, segue a esteira de farta legislação intervencionista, que caracterizou os primeiros passos do Estado assistencialista e da socialização do Direito Civil. ${ }^{30}$

O Estado Assistencialista - Welfare State, État Providence ou Stato del Benessere - não mais se limita a mediar as relações privadas e elaborar as normas, mas passa a intervir fortemente para buscar objetivos fundamentais de justiça social, conforme descreve Gustavo Tepedino: "A meta da justiça retributiva, conquista da Revolução Francesa, dá lugar à justiça redistributiva, com o acentuado intervencionismo estatal e dirigismo contratual que, no Brasil, é fartamente documentado a partir dos anos 30. A propriedade passa a ter uma função central de redistribuição de rendas. A titularidade da situação proprietária passa a implicar para seu titular, no concomitante respeito a crescentes situações não-proprietárias. A destinação do bem apropriado ora é determinada por lei, ora é controlada e restringida, ora é proibida, caracterizando-se o direito de propriedade menos pelo seu conteúdo estrutural acima descrito e mais pela destinação do bem sobre o qual incide ou, ainda, por sua potencialidade econômica. ${ }^{31}$

Acrescenta o autor que a fórmula jus utendi et abutendi é insuficiente para descrever a relação jurídica proprietária e começa a ser questionado o direito proprietário como um direito único. Verifica-se que a estrutura do Direito, fixada pelo Código Civil, é insuficiente para abrigar a multiplicidade de situações proprietárias, distintas umas das outras em função da destinação do bem e da disciplina aplicável na relação intersubjetiva em que se inseriram.

Em 1939, Filippo Vassali e, depois, Salvatore Pugliatti, no estudo La Proprietá e le Proprietá, de 1954, propõem a desintegração conceitual de propriedade. Pugliatti alude a "propriedades". Contra o conceito não-unitário de propriedade ou noção pluralista de propriedade, cite-se Cariota Ferrara. Reafirma, ainda, o conceito plúrimo de propriedade, Ricardo César Pereira Lira, notável especialista em Direito das Coisas - propriedade urbana e fundiária - a quem se

30. "Contornos constitucionais da propricdade privada". Temas de Direito Civil. Rio de Janciro: Rcnovar, 1999, p. 267 c ss., cspecialmentc p. 269.

31. "A nova propricdade (o scu contcúdo minimo cntrc o Código Civil, a legislação ordinária, c a Constituição)". Revista Forense, v. 306, pp. 73-8. 
deve o estudo pioneiro do novo direito de propriedade aplicado às favelas, uma realidade brasileira. ${ }^{32}$

A Constituição, de 1967, e a sua Emenda de 1969 consagraram o princípio da função social da propriedade, de forma mais ampla, provavelmente porque já se encontrava promulgado o Estatuto da Terra (1964) que estabeleceu que à propriedade privada da terra cabe intrinsecamente uma função social e seu uso é condicionado ao bem-estar coletivo, previsto na Constituição Federal e caracterizado nesta lei (art. 12).

Assegurou, o Estatuto da Terra, ainda, o acesso à propriedade da terra, condicionada pela sua função social (art. $2^{\circ}$ ) e determinou as sanções (art. 13) impostas à observância do ordenamento constitucional e da lei ordinária.

A nova Carta brasileira, Constituição Federal promulgada em 05 de outubro de 1988, no Título II, relativo aos Direitos e Garantias Fundamentais, garantiu o direito de propriedade (art. $\left.5^{\circ}, \mathrm{XXII}\right)$, mas condicionou-o à função social, determinando que a propriedade a atenderá (art. $5^{\circ}, \mathrm{XXIII).} \mathrm{No} \mathrm{Título} \mathrm{VII,} \mathrm{Da} \mathrm{Ordem} \mathrm{Econômica} \mathrm{e}$ Financeira, a Constituição - no capítulo referente à Política Agricola e Fundiária e Reforma Agrária - estabeleceu os requisitos que devem ser atendidos, de modo simultâneo, a fim de que a função social, que é inerente à propriedade rural, possa ser integralmente cumprida.

Observe-se que a Constituição que ora vige detalhou, mais que as suas antecessoras, a noção de função social, não dizendo o que ela $\dot{e}$, mas estabelecendo parâmetros que permitem a construção da sua idéia. Na verdade, a Constituição inseriu a função social da propriedade como um dos megaprincípios da ordem econômica e, também - já se mencionou - a elenca entre os direitos e as garantias fundamentais.

Gustavo Tepedino bem observa que esta inserção constitucional, entre os direitos e as garantias fundamentais, teve o escopo de elevar a determinação de atendimento à função social ao patamar de regra fundamental, apta a instrumentalizar todo o tecido constitucional e, por via de conseqüencia, todas as normas infraconstitucionais, criando um parâmetro interpretativo do ordenamento juridico. ${ }^{33}$

Segundo Gustavo Tepedino o que diferencia o ângulo de consideração da função social, na Constituição Federal de 1967-69 e na de 1988 é que, enquanto naquela a função social era princípio da ordem econômica e social, na Constituição vigente é encartada no âmbito dos direitos e garantias fundamentais (inciso XXIII do art. $5^{\circ}$ ).

32. Consulte-sc, do autor, Elementos de Direito Urbanistico. Rio de Janciro: Renovar, 1997, especialmentc p. 364 .

33. Gustavo Tepedino. "Contornos constitucionais da propricdade privada", cit., pp. 267-292. 
Há disciplinas diversas para a propriedade, segundo sua potencionalidade quanto à destinação econômica. $\mathrm{O}$ art. 185 da Constituição Federal estabelece serem inexpropriáveis, para fins de reforma agrária: "I- a pequena e média propriedade rural, assim definida em lei, desde que seu proprietário não proprietário não possua outra; II- a propriedade produtiva."

Gustavo Tepedino invoca, também, o art. $5^{\circ}$, XXVI, segundo o qual a pequena propriedade rural, assim definida em lei, desde que trabalhada pela familia, é impenhorável para pagamento de débitos decorrentes de sua atividade produtiva, dispondo a lei sobre os meios de financiar seu desenvolvimento. Elenca, ainda, o Capítulo III do Título VII (arts. 184 a 191) que trata da política agrícola e fundiária e da reforma agrária, no qual se encarta a norma que cuida das restrições de aquisição de propriedade rural por estrangeiros (art. 190).

Antes, o autor em consideração enfatiza a importância do art. 183 da Constituição que trata de usucapião urbano, reconhecido a quem possuir como sua, área urbana de até $250 \mathrm{~m}^{2}$, por cinco anos, de modo ininterrupto e sem oposição, utilizando-a para sua moradia ou de sua família.

Lateralmente à modalidade urbana de usucapião situa-se o usucapião especial ou usucapião agrário, ou, ainda, usucapião 'pro labore' A ele aludem as Constituições de 1934, 1937, 1946, 1967-69, e a de 1988, bem como o Estatuto da Terra (Lei n. 4.504, de 30 de novembro de 1964, art. 98), regulado pela Lei n. 6.969, de 10 de dezembro de 1981. Usucapião pro labore, como o próprio nome indica, é o que permite a aquisição do domínio pelo trabalho do possuidor da gleba rural, bem como pela sua morada efetiva no imóvel possuído, pois esta espécie de usucapião é modalidade que personaliza o usucapiente e que somente se pode verificar relativamente $\grave{a}$ propriedade agrária como bem de produção. Trabalho produtivo e morada habitual são, pois, os requisitos da denominada posse agrária ${ }^{34}$. posse esta que se distingue da posse comum exatamente pelo fato da produtividade e da pessoalidade do ato agrário, impregnando-se, como tudo o mais que compõe o conteúdo do Direito Agrário, da milenar função social da propriedade. E esta é a posse ad usucapionem da espécie em exame, isto é, a posse hábil para gerar o usucapião especial. ${ }^{35}$

Em 18 de junho foi aprovado pelo Senado Federal e encaminhado à

34. Sobre possc agrária, lcia-sc mais, abaixo, nestc mesmo cstudo, sob o item 3.

35. Gisclda M. Fcrnandes Novacs Hironaka, "Usucapião Espccial: caracteristicas do imóvel usucapiendo $\mathrm{cm}$ face da Constituição Fcderal de 1988”, Direito Civil-Estudos. Bclo Horizontc: Del Rey, 2000 , pp. 195-198. 
sanção presidencial, o Projeto de Lei n. 181, de 1989 (n. 5.788, de 1990, da Câmara dos Deputados), transformando-se na Lei n. 10.257, de 10 de julho de 2001, conhecida como Estatuto da Cidade.

A lei em tela regulamenta os arts. 182 e 183 da Constituição Federal e estabelece as diretrizes gerais da política urbana e dá outras providências.

Importante instrumento de política urbana, desde há muito tempo tem sido alvo da preocupação dos juristas, entre os quais salienta-se a valiosa contribuição do professor Ricardo César Pereira Lira, composta de ensaios, palestras e proposta de projeto de Lei. ${ }^{36}$

Além do usucapião especial de imóvel urbano, previsto nos arts. $99^{\circ}$ a 20, estabelece a Lei, tal como o Projeto n. 181/89, do qual se origina, a concessão de uso especial para fins de moradia e o direito de superficie (arts. 21 a 24) já proposto por Ricardo Lira, como solução para a questão da moradia, juntamente com a concessão de direito real de uso. Embora recente, a Lei n. 10.257, de 10 de julho de 2001, já foi objeto de relevantes estudos doutrinários, entre os quais o coordenado pela ilustre administrativista Odete Medauar. ${ }^{37}$

Após análise da Constituição Federal, Gustavo Tepedino conclui, em oportuno resumo, que o constituinte criou estatutos diversos para a propriedade, segundo a sua localização (rural ou urbana), ou segundo a sua potencialidade (produtiva ou não-produtiva), ou, ainda, segundo a sua titularidade (por nacionais ou estrangeiros).

Quanto à mulher, convém observar que a Constituição previu expressamente - em boa hora, ainda que tardiamente - que ela pode adquirir o domínio, de área urbana, de até $250 \mathrm{~m}$, nos termos do $\S 1^{\circ}$ do art. 183 , o que se coaduna com a igualdade entre homem e mulher - igualdade real e não-formal. ${ }^{38}$

Pode ela, ainda, ser beneficiária da distribuição de imóveis rurais pela reforma agrária, nos termos do parágrafo único do art. 189.

Quanto ao usucapião pro labore, previsto no art. 191, apesar de não haver contemplação expressa, parece claro que a mulher também poderá usucapir, nas

36. Consultc-sc a integra dos cnsaios c proposta de projeto de lci $\mathrm{cm}$ Direito Urbanístico Brasileiro, citado.

37. Estatuto da Cidade. Lei n. 10.257, de 10.07.2001. Coordenação de Odetc Medauar c Fernando Dias Menczes de Almcida. São Paulo: Revista dos Tribunais, 2002.

38. Sobre a igualdade real $\mathrm{c}$ não apenas formal entre homem $\mathrm{c}$ mulher, na Constituição Federal, consulte-se de Silmara Juny de Abreu Chinclato c Almeida Do nome da mulher casada: Direito de Familia e Direitos da personalidade. Rio de Janciro, Forense Universitária, 2001. O tema ć tratado nas páginas 37 c 73-76. 
mesmas condições que o homem, aplicando-se aqui a igualdade real ou substancial prevista no art. $5^{\circ}$, I, da Constituição Federal. ${ }^{39}$

$\mathrm{Na}$ análise, então, do desenho constitucional acerca do quanto possa dizer respeito e interessar, direta ou indiretamente, ao instituto da propriedade, relembrese o importante art. 186, que fornece diretrizes seguras para o conteúdo da função social da propriedade. Também não se pode deixar de relevar o principio da dignidade da pessoa humana, cláusula geral de interpretação (art. $1^{\circ}$, III, da Constituição Federal) e nem mesmo o art. $3^{\circ}$, que retrata os objetivos fundamentais da República Federativa do Brasil, mas que, na verdade, elenca o mais formidável rol de intenções que pode ser querido por uma nação sadia - livre, justa e solidária - e seu povo, elenco no qual figura expressamente: "IV-promover o bem de todos, sem preconceito de origem. raça, sexo, cor, idade e quaisquer outras formas de discriminação"

Todos esses dispositivos, que configuram a tábua axiológica constitucional, devem ser interpretados em conjunto, o que será, por certo, o bastante para afirmar que propriedade produtiva não é a que produz no interesse exclusivo e particular do proprietário. A produção há de atender ao interesse da coletividade, há de ser feita da forma solidarista, na feliz expressão de Gustavo Tepedino. ${ }^{40}$ Se ela tiver cunho especulativo, não atenderá sua função social, podendo ser desapropriada.

O conceito de função social é, efetivamente, muito dificil de ser enunciado com precisão, dada a sua conotação abstrata. Mas dúvida não resta de que ela é idéia inarredavelmente instalada bem no âmago do conceito de direito de propriedade, vinculando-o, em definitivo, ao destino previsto por aquela funcionalidade.

Sem dúvida nenhuma, a doutrina da função social da propriedade, como bem enuncia Luiz Edson Fachin, revela uma profunda alteração de natureza conceitual no regime tradicional; mas não é, todaviá - adverte bem o autor - uma questão de essência, mas sim pertinente a uma parcela da propriedade que é a sua utilização. ${ }^{4 !}$

Carlos Alberto Bittar, entre os primeiros autores nacionais a escrever sobre o perfil constitucional da propriedade, conforme estampado em $1988,{ }^{42}$ referiu-

39. Gisclda M. Fcrnandes Novacs Hironaka, "Usucapião Espccial: caractcristicas do imóvel usucapiendo cm face da Constituição Federal de 1988", cit., p. 197.

40. "Contornos constitucionais da propricdade privada", cit., p. 274. O tcrmo "solidarista" c não, "solidário", ć cmpregado pclo autor. Apresenta a vantagem de não se confundir com a solidariedade, termo técnico próprio ao Dircito das Obrigaçõcs.

41. Luiz Edson Fachin. Função Social da Posse e da Propriedade Contemporânea. cit., p. 18.

42. Carlos Albcrto Bittar, "Os Dircitos Reais na Constituição de 1988". A Propriedade e os Direitos Reais na Constituição de 1988. (coord. Carlos Alberto Bittar). Sào Paulo: Saraiva, 1991, pp. 1-13. 
se ao fato de ter, a nova sistematização, absorvido a textura insita da Constituição imediatamente anterior, vale dizer, a posição adotada pelo legislador constitucional da Carta em vigor foi a de manter a concepção ocidental de propriedade pela qual resta reservado à pessoa, como um dos direitos fundamentais, as suas titularidades, bem como o uso e gozo dos bens de sua propriedade, mas desde que esta utilização se fizesse sob a ética social, com a anteposição de certos limites atinentes ao ajuste desse direito a ditames de ordem pública. ${ }^{43}$

O mais importante aspecto que pode ser certamente visualizado, por força desta absorção constitucional da funcionalidade da propriedade, reside na perfeita e harmônica postura do legislador que, por um lado, preserva a propriedade como um dos pilares da organização social e jurídica em nosso país, inatacável, a rigor constitucional, dada a sua condição de direito fundamental, mas que, por outro lado, resiste e não propicia perigosas extensões do sentido social ao instituo ancestral, verdadeiras exacerbações que intentavam legitimar invasões de terras alheias, ocupações de espaços imobiliários de outrem e operações outras desse naipe, conforme as exatas palavras do já falecido professor das Arcadas. ${ }^{44}$

Enfim, a função social corresponde a uma formulação contemporânea da legitimação do titulo que encerra a dominialidade, como com absoluta perfeição enuncia Luiz Edson Fachin. ${ }^{45}$

Francisco Amaral, no ensaio "A autonomia privada como principio fundamental da ordem juridica. Perspectivas estrutural e funcional" ${ }^{46}$ afirma que uma das características dos estudos jurídicos contemporâneos é a conexão entre a teoria estrutural do direito e o ponto de vista técnico-jurídico, de um lado e, de outro, a teoria funcional do direito e o ponto de vista sociológico.

Esta conexão é essencial para o jurista saber não apenas como o direito é feito, mas também para o que serve, isto é, sua causa final. Invocando José Manuel Durão Barroso, hoje primeiro-ministro de Portugal, no verbete "Função" na PolisEnciclopedia Verbo 2, p. 1.606, o autor afirma que assim aparece o conceito de função

43. Carlos Alberto Bittar, idem, p. 4.

44. Carlos Alberto Bittar, idem, pp. 7 c 10, respectivamentc.

45. Luiz Edson Fachin. “A Cidade Nuclcar c o Dircito Pcriférico (reflexões sobre a propricdade urbana)". Revista dos Tribunais, 1996, v. 743: 107-110, p. 109.

46. Francisco Amaral, "A autonomia privada como princípio fundamental da ordem jurídica. Perspectivas cstrutural c funcional", Estudlos en homenagem ao Prof. Doutor António Ferrer Correia, v. II. Bolctim da Faculdade de Dircito. Universidade de Coimbra, número cspecial, Coimbra, 1989, pp. 5-41. 
em Direito, designando o papel que um princípio, norma ou instituto desempenham no interior de um sistema ou estrutura, de partes interdependentes. O Direito começa a interessar-se por funções distributivas, promocionais ou inovadoras - abandonando a costumeira função repressiva, principalmente na relação do Direito com a Economia. Daí falar-se na função econômico-social dos institutos jurídicos, lembrando-se a obra de Karl Renner, primeiramente em matéria de propriedade e depois, de contrato: Emprestar ao direito uma função social significa considerar que a sociedade se sobrepõe ao interesse individual, o que justifica acabar com as injustiças sociais. Função social significa não individual, sendo critério de valoração de situações jurídicas conexas ao desenvolvimento das atividades da ordem econômica. Seu objetivo é o bem-comum, o bem estar econômico coletivo. ${ }^{47}$

Francisco Amaral enfatiza, também, que a função social se configura como princípio ordenador da disciplina da propriedade e do contrato, legitimando a intervenção legislativa do Estado e a aplicação de normas excepcionais, operando ainda como critério de interpretação das leis: "A função social é, por tudo isso, um principio geral de atuação juridica, um verdadeiro standard jurídico, uma diretiva mais ou menos flexivel, uma indicação programática que não colide nem ineficaciza os direitos subjetivos, apenas orienta o respectivo o exercicio na direção mais consentânea com o bem-comum e a justiça social. Podem assim coexistir o direito subjetivo e o standard jurídico, e conceitos até então considerados incompativeis, como direito e função, coexistem na realidade legislativa, em nivel de principios" 48 Para ele, a teoria da função econômico-social dos institutos jurídicos é o produto-síntese das tendências axiológicas contemporâneas que levam ao paradigma da economia dirigida. $\mathrm{O}$ contrato, instrumento da autonomia privada, é o campo de maior aceitação dessa teoria, acollhida, primeiramente, no Código Civil italiano, art. 1.322. Do mesmo modo, portou-se o Código Civil português que, no art. 405 combinado com o art. 280, fixou limites ao exercício da autonomia privada estabelecendo a nulidade do negócio jurídico contrário à ordem pública ou aos bons costumes.

O novo Código Civil brasileiro prevê no art. 421 que "a liberdade de contratar será exercida em razão e nos limites da função social do contrato". Muito se tem criticado a redação deste dispositivo da nova legislação civil brasileira, embora a inegável preciosidade do espírito contido no preceito legal que inaugura do Livro dos

47. "A autonomia privada como princípio fundamental da ordem juridica. Perspectivas cstrutural $\mathrm{c}$ funcional", cit., p. 38.

48. Idcm, ibidem. 
Contratos no novo Código. São dois os grandes problemas de má técnica redacional que habitam o âmago do extraordinário art. 421, e é muito fácil reconhecê-los, de molde a se insistir, constantemente, que o preceito precisa mesmo ser modificado, a fim de que possa alcançar a otimização que permita se revele, dentro nele e em sua total consagração, o grande princípio da função social.

Bem adverte Antonio Junqueira de Azevedo ${ }^{49}$ - acompanhando, nesse passo, a lição de Álvado Villaça de Azevedo ${ }^{50}$ - que a função social do contrato é um limite para a liberdade contratual, e não um limite à liberdade de contratar. Mas, mais que isso - ele prossegue - esse artigo tem um viés trágico, porque determina textualmente que a liberdade de contratar será exercida 'em razão da função social.

Ora, nem se trata de liberdade de contratar, nem deverá ser exercida em razão da função social do contrato. Na verdade, trata-se de liberdade contratual, aquela pertinente à limitação do conteúdo do contrato, por força de norma de ordem pública, e não de liberdade de contratar, esta sim fundada na dignidade da pessoa humana e resultante da alta expressão da autonomia privada e, bem por isso, ilimitada. Além disso, a liberdade contratual poderá encontrar, na função social que é inerente ao contrato, uma limitação à sua extensão meramente volitiva, uma vez que nem sempre os contratantes poderão, sem estes freios, fixar livremente as cláusulas de seu contrato. E quando isso se der, quer dizer, quando certas cláusulas estiverem cogentemente registradas no contrato conforme a determinação de norma de ordem pública, se compreenderá, então, que a função social exerceu o seu verdadeiro papel, conforme convém. Exerceu o papel limitador da vontade dos contratantes, restringindo-lhes a liberdade contratual, e não qualquer outro papel que fosse delineado por um viés de fundamentação ou de razão de ser da própria restrição cometida. Em desacerto, portanto, o mesmo art. 421, em dois momentos subseqüentes de sua composição legislativa, quando descreve que a 'liberdade de contratar' será exercida 'em razão' e no limite da função social do contrato. Insiste-se, acompanhando Antonio Junqueira de Azevedo e Álvaro Villaça de Azevedo: a função social de que se cuida aqui, é função limitadora à fixação absolutamente livre do conteúdo

49. Assim manifcstou-sc o civilista paulista $\mathrm{cm}$ memorável palestra que proferiu no I Seminário sobre o Novo Código Civil Brasileiro:o que muda na vida do cidadão, promovido pcla Ouvidoria Parlamentar c Terceira Sccretaria da Câmara dos Deputados, cm Brasilia (DF), cm 04.06.2002.

50. Verbetc liberdade contratual, Enciclopćdia Saraiva do Dircito 49/370-371, São Paulo: Saraiva, 1977. 
contratual, mas não é fundamento para justificar ou sustentar a restrição imposta em certos casos. ${ }^{51}$

Consagrada a função econômico-social do contrato e, implicitamente, a autonomia privada, reconhece-se, afinal, que este poder jurídico deve limitar-se pela ordem pública e pelos bons costumes, de modo geral e, em particular, pela utilidade que possa ter na consecução dos interesses gerais da comunidade, com vistas ao desenvolvimento econômico e ao seu bem estar promovendo a justiça, na sua modalidade distributiva ou na dimensão de justiça social" ${ }^{52}$

4. A propriedade e a posse. A natureza jurídica do direito de propriedade: a influência da concepção absolutișta e a influência da concepção personalista. O fenômeno possessório e a sua intrinseca funcionalidade social: a teoria possessória civilista e a teoria possessória agrária.

O Direito brasileiro acolhera, como demonstra a legislação de $1916,{ }^{53}$ a concepção individualista e absolutista acerca da propriedade e da investigação acerca de sua natureza jurídica.

Desde Clóvis Bevilaqua, e já na esteira do pensamento de Lafayette, seguindo-se tantos outros grandes nomes do painel jurídico brasileiro - como Carvalho Santos, por exemplo - é possivel visualizar a marcante presença desta influência que reconheceu a propriedade como uma relação exclusiva entre a pessoa e a coisa. Tão longe chegou tal formulação que se defendeu a idéia de que o desenho jurídico do direito real pressupunha, tão-somente, o sujeito ativo (titular do direito) e a coisa sobre que recaia.

A realidade é que os ilustres autores estavam tão jungidos à realidade social e econômica vigente - conforme enfatiza Emílio Gischkow - que omitiam o

51. Gisclda M. Fernandes Novacs Hironaka, Contrato: cstrutura milcnar de fundação do dircito privado. Supcrando a crisc c rcnovando princípios, no início do vigćsimo primciro sćculo, ao tempo da transição Icgislativa civil brasilcira, palcstra proferida no $5^{\circ}$ Scminário de Estudos sobrc o Novo Código Civil, promovido pela Escola Judicial Des. Edćsio Fernandes c pelo Tribunal de Justiça do Estado de Minas Gerais, cm Ubcrlândia, cm 23 de agosto de 2002 c Rcvista do Advogado - Novo Código Civil - Aspectos Rclcvantcs, Associação dos Advogados de São Paulo, ano XXII, n. 68, dczcmbro/2002, pp. 79-86.

52. "A autonomia privada como princípio fundamental da ordem jurídica. Perspectivas cstrutural c funcional", cit., p. 40.

53. Código Civil Brasilciro - Lci n. 3.071 de $l^{\circ}$ de janciro de 1916 - que esteve em vigor, entre nós, desde o dia $1^{\circ}$ de janciro de 1917 até o dia 10 de janciro de 2003. Foi substituido pclo novo Código Civil brasilciro - Lei n. $10.406 \mathrm{de} 10$ de janciro de 2002 - que se cncontra cm vigor desde o dia $11 \mathrm{de}$ janciro de 2003. 
aspecto elementar de toda a atividade jurídica, ou seja, a relação interpessoal. Emitindo a regra juridica um preceito, este contém um comando, ordem que se dirige a outro sujeito de direito. ${ }^{54}$

Efetivamente era frágil a posição e mantê-la tornou-se tarefa dificil, exatamente à face da reação forjada contra essa linha de concepção, reação que emergiu com a teoria personalista que defende, irrestritamente, a natureza interpessoal da relação jurídica real.

Essa teoria demonstrou que a todo direito subjetivo corresponde uma obrigação, de sorte que a relação jurídica, pretensamente exclusiva, entre o titular e a coisa, é singelamente errônea. Cunha Gonçalves, por exemplo, e entre outros, afirmou que nos direitos reais há sempre um sujeito passivo; apenas que este sujeito passivo é indeterminado e sua obrigação é negativa.

Por essa obrigação negativa o sujeito passivo - seja ele quem for - está obrigado a uma permanente abstenção, consistente em não-turbar, em não- agredir, em não-impedir o exercício, em não-lesar a coisa que a outrem pertença.

Assim sendo, a relação do titular do direito real é com todos, a respeito da coisa; e não uma relação do titular com a própria coisa.

Afastada a estreita e irreal concepção absolutista a respeito do direito de propriedade, a conseqüência imediata que aflorou, felizmente, foi o relevo dado ao caráter social do direito, uma vez que a relação jurídica apenas vincula pessoas, apenas determina a conduta de um homem à face de outro homem. Esta é a concepção personalista acerca da natureza jurídica do direito de propriedade.

No que diz respeito à estrutura desse direito, a mais tradicional doutrina já desmembrava, como se faz ainda hoje, o grande espectro deste importantíssimo direito real em distintas faculdades jurídicas, ou atributos jurídicos, estampando os poderes que são conferidos ao seu titular, quais sejam, o direito de usar, o direito de gozar ou fruir, o direito de dispor e o direito de perseguir e reaver a coisa do poder de quem quer que injustamente a possua.

Da análise cuidadosa desta plêiade de direitos derivados, ou faculdades jurídicas, vislumbra-se com clareza - e a melhor lição é a de Gustavo Tepedino - duas angulações distintas, mas harmônicas, por meio das quais se apresentam as atribuições qualitativas de um e de outro destes variados poderes. Vale dizer, com o autor: uma angulação econômica e interna da estrutura do direito, relacionada às faculdades de

54. Emilio Gischkow, Principios de Direito Agrário, cit. 
usar, gozar e dispor da coisa; e uma angulação juridica ou externa desta mesma estrutura, relacionada à faculdade de reivindicação da coisa. Por meio do exercício dos sub-direitos que compõem o primeiro aspecto estrutural - usar, gozar e dispor - é que o titular do direito de propriedade afere compensações econômicas; e é pelo exercício da derradeira das faculdades - reaver a coisa - que o titular deste direito efetivamente o tutela e protege, excluindo-o das ingerências alheias. ${ }^{55}$

Assim estruturado, o direito pleno, aglutinador das várias faculdades juridicas, ainda que considerado tão forte que oponível erga omnes, se apresenta estático, desprovido de movimento, sem expressão que o exteriorize, carente de efetividade, ausente de exercício. A dar-lhe este traço de dinâmica, de mobilidade, de expressão externa e de funcionalidade, colabora o seu outro vigoroso aspecto, de inserção constitucional, ínsito ao seu exercício, utilização e destinação: a função social que lhe é inerente.

Ora, se jả desde a lição iheringeana mais tradicionalmente ouvida sabese que a posse é a exteriorização da propriedade, sabe-se que é a posse quem vivifica e confere efetividade ao ancestral direito real, nada mais simples e natural que a conclusão que prestigia a identidade descortinada entre a posse e o princípio da função social da propriedade.

A lei, ao lado da garantia e proteção que confere à propriedade, estabeleceu normas de proteção também à posse, esta simples situação de fato, exatamente porque ela aparenta ser uma situação de direito e porque tem a lei em vista evitar preponderar a violência, tendo como nefasta e imediata conseqüência a quebra da harmonia social.

Procurando explicar o fenômeno da posse, os juristas apresentaram importantes e, hoje, clássicas teorias, as quais são invariavelmente demonstradas em todos os estudos que investiguem o tema. Destacam-se, pela distinta construção, as teorias elaboradas pelo gênio criador de Savigny, com sua teoria subjetiva, e pela inteligência extraordinariamente especulativa de Von Ihering, com sua teoria objetiva.

Para Savigny, a posse consiste no poder de dispor fisicamente da coisa, com intenção de dono e de defendê-la contra terceiros. Infere-se, imediatamente, os dois elementos essenciais desta teoria, vale dizer, de um lado, o elemento material que Savigny denominou corpus, refletindo a apreensão fisica da coisa, e de outro lado, o elemento moral, denominado animus domini, animus possidendi, animus rem sibi

55. Gustavo Tepedino. "Aspectos da propricdade privada na ordem constitucional". Estudos Juridicos, (coord. James Tubenchlak c Ricardo Bustamantc). Rio de Janciro: 1991, p. 314. 
habendi, ou, simplesmente, animus, a significar a intenção de ter a coisa como própria, de agir como se seu dono fosse, de se comportar como seu proprietário o faria.

Segundo Savigny, a posse só estaria caracterizada se concorressem ambos os elementos, pois, faltando corpus, inexistiria a relação pretendida, e faltando animus, não haveria posse, mas apenas mera detenção, circunstância incapaz de gerar efeitos jurídicos.

Von Thering, por sua vez, opositor de Savigny, autor da teoria objetiva, considerou que a posse é a condição do exercicio da propriedade, pois esta sem aquela é como um cofre sem chave. ${ }^{56}$ Não admitiu Von Ihering, portanto, a distinção que Savigny fez entre corpus e animus, entendendo que este último está contido naquele, de sorte a ser possivel que possuidor é aquele que age, em face da coisa corpórea, como se fosse proprietário, pois a posse nada mais é que a exteriorização da propriedade. Portanto, o possuidor é presuntivamente o proprietário.

De pronto observa-se, pela rápida releitura das fundamentais teorias acerca da posse, que os teóricos civilistas, sob a égide do pensamento individualista e liberal, preocuparam-se em elaborar teses possessórias que subsumiram a posse à propriedade. Resultou, na verdade, que tanto uma quanto outra teoria admitiam a possibilidade de uma interposta pessoa - fosse o representante, o preposto ou mesmo o simples servidor da posse - realizar atos de aquisição e de manutenção da posse, como se tais atos houvessem sido praticados pelo próprio titular, já que, em nome deste, aquele adquire ou conserva o animus domini. Mesmo sob o matiz da teoria iheringeana, é provavelmente possível concluir-se por idêntico raciocínio, isto é, a possibilidade da presença de interposta pessoa que realiza atos materiais dirigidos à conservação ou aquisição, fazendo-o em nome do titular.

Contemporaneamente, o fenômeno da posse deve ser encarado sob novas concep̧̧̃es, sob diverso enfoque, à luz de novos paradigmas, mormente no que tange à segurança acerca da natureza jurídica do imóvel rural como bem de produção que indubitavelmente é. A principiologia própria do Direito Agrário é quem traça os contornos desta nova e especialíssima ordem, de sorte a deixar assentado, com firmeza e precisão, que o imóvel rural é um dos valores máximos na apreciação das relações jurídicas que envolvam a propriedade, dado que é este valor que configura a forma e o

56. Sobre posse $\mathrm{c}$ detenção $\mathrm{c}$ as diferentes visões da teoria objetiva de Von lhering $\mathrm{c}$ a tcoria subjetiva, de Savigny, consultc-sc o cnsaio "A detenção no Dircito Civil brasilciro", do ilustre civilista Josć Carlos Morcira Alves, que há muito tem se dedicado ao tema dos dircitos reais. $\mathrm{O}$ cnsaio $\mathrm{cm}$ tcla ć parte do livro Posse e propriedade (coordenação de Yusscf Said Cahali). São Paulo: Saraiva, 1987, pp. 1-31. 
conteúdo à denominada posse agrária e que atua, de modo relevante, na conjugação dos fatores de produção econômica. ${ }^{57}$

Sob a visão iheringeana observa-se que a posse agrária, assim como a comum, é conformada estruturalmente por dois elementos, corpus e animus; no entanto, a configuração destes dois elementos estruturais se externa de maneira distinta, em sede teórica, no que concerne ao estudo da posse agrária.

Assim, o elemento corpus, fator objetivo, é configurado por atos materiais que expressam a vinculação direta e imediata do possuidor à terra, por meio da organização dos fatores de produção, para o desenvolvimento da adequada e racional empresa agrária. Já o elemento animus, fator subjetivo, revela-se como a intenção do possuidor de exercer a atividade agrária para, daí, extrair riquezas. O possuidor deseja explorar a propriedade, economicamente, com a finalidade da produção de bens consumíveis, o que proporcionará tanto o proveito próprio quanto o proveito de toda a sociedade. Por isso, sua intenção - o animus iheringeano - é externada pelo trabalho agrário que alcança a sua completude com a obtenção do produto final oriundo do desempenho desta atividade..$^{58}$

57. A respcito, v. Antonio de Mattos Neto. A posse agrária e suas implicações juridicas no Brasil. Bclém: Ccjup, 1988.

58. Não pensa assim, contudo, Antonio Junqueira de Azevedo que ao criticar de modo construtivoobjctivo o então Projeto de Código Civil obscrvou que a posse, ali, ć vista cxclusivamentc como exteriorização da propricdadc, à mancira de Von Ihcring, visão curopćia que não sc coaduna com a realidade brasilcira. Elc afirma, $\mathrm{cm}$ entrevista que concedeu ao jornal Tribuna do Dircito, $\mathrm{cm}$ março de 1998, p.19, que a dependência conceptual da posse à propriedade , como única visão possivel, tem algo da visão do burguês europeu; afinal, a posse também pode existir de forma absolutamente independente da propriedade. As duas visóes não se excluem. Para o povo brasileiro - especialmente os favelados e pequenos agricultores -, a posse ć dircito autônomo que nada tem a ver com a propriedadc; a posse é direito que se compra, vende e deveria, portanto, estar contemplada entre os direitos reais. Para Junqucira, a possc européia - conforme cle denomina a posse iheringcana - bem poderia ser suficiente para fundamentar o usucapião tradicional (ordinário c cxtraordinário) que admitc à aquisição da propricdadc, por csta via. Mas seria insuficiente, $\mathrm{c}$ nisso cle tem boa razão, para justificar csse mesmo percurso, se o cnfoque se deslocasse para outras modalidades de usucapião. Elc disse, ainda naquela entrevista: nós temos também o usucapião constitucional (rural e urbano) que não está baseado na exteriorização ou na aparência de propriedade, e sim, na transformação do imóvel; seu fundamento é outro; trata-se de verdadeira especificação de imóvel; a propriedade é adquirida por força da modificação do imóvel, tal e qual o especificador que adquire um bem móvel pelo trabalho que aplica sobre ele (arts. 611 a 614 do atual Código Civil)! Se a posse, no Projeto, fosse incluida entre os direitos reais, o possuidor, especialmente na posse sobre imóvel, seria estimulado a fazer investimento no imóvel; com o registro da posse, poderia obter financiamento e não seria tentado a deteriorar o meio ambiente.

59. Em scntido distinto a cssa posição mencionada cm antcrior nota de rodapć, parcec colocar-sc Rui Gcraldo Camargo Viana quando afirma: Apenas fico um pouco irritado ao observar os attores repetindo que aqui se aceitou, no nosso sistema, a teoria de Von Ihering de que a posse se clarifica apenas pelo corpus, sem a necessidade do animus. É uma erronia. Nosso Código exige, sim, na formatação da posse. 
Assim é possível dizer que o exercício da posse agrária, isto é, a sua face externa e dinâmica, se realiza por meio da execução da própria atividade agrária que envolve todo um elenco de atos que o possuidor agrário realiza com vistas à exploração econômica do bem, todos eles sujeitos aos riscos correlatos da natureza e suas soberanas forças, mas que, afinal, se desencadeiam em harmonia perfeita e singular, realizando o ciclo biológico do produto almejado. Toda esta atividade é, então, desenvolvida assim, dinamicamente, e gera expectativa de lucro; seu resultado bem-sucedido beneficiará o próprio rurícola e garantirá o seu próprio sustento e consumo, mas, mais que isso, beneficiará, por via de conseqüência, a sociedade como um todo.

Este movimento ativo do possuidor agrário, então, é que retrata o elemento subjetivo de sua posse, elemento este que, mais que singelo animus, é na verdade uma árdua e cotidiana realização do homem sobre a terra, na expectativa de exaltar-lhe $o$ atributo de bem de produção, quando a provoca para o cumprimento de sua finalidade máxima, que é a função social da propriedade imobiliária rural. $\mathrm{Na}$ atualidade, pois, apresenta-se como verdadeiro princípio basilar agrário esta preferência que tem o rurícola pela empresa organizada à modelagem do cultivo direto, ocasião em que ele busca organizar os fatores de produção privilegiando a mão-de-obra própria e a de sua família. ${ }^{60}$

Dai ser possível bem compreender porque é que a concepção atual de posse agrária subsume-se e identifica-se fundamentalmente com este viés de utilização adequada e racional da terra, fazendo-a produzir e conferindo-lhe a efetivação da função social que lhe é inerente, exatamente por meio do desempenho desta atividade que, na linguagem legal e desde o regime sesmarial, significa o atributo da cultura efetiva.

Mas não se exaure aí, apenas, a diferença entre a posse comum e a posse

o elemento volitivo. Não há posse sem vontade. Mera detenção não é posse, quem não tem a intenção de possuir não é possuidor. Costumo brincar com meus alunos, fazendo uma comparação. No Viaduto do Chá, em São Paulo, está um maneta atravessando a rua. Uma ventania arranca um chapéu de um cidadão e lhe cai sobre a cabeça. O chapéué maior e se enterra na sua cabeça. Pergunto: ele está possuindo ou está sendo possuido pelo chapéu? Não é intencional. Ele não pode tirar o chapéu porque não tem mãos. Quanto mais ele chacoalha a cabeça, mais o chapéu afunda nela. Aquilo não é posse. porque esta é um estado de fato. Já o ladrão que roubou o chapéu de un cidadão, colocou na cabeça e fugiu é possuidor. Então, dizer que a posse não tem elemento subjetivo é uma tolice. No fundo, as divergências entre Von Ihering e Savigny são mais aparentes que reais. Na realidade, ambos têm esse elemento volitivo. (Direitos Reais e o novo Código Civil Brasileiro, palcstra profcrida no l Scminário sobrc o Novo Código Civil Brasilciro: o que muda na vida do cidadão, promovido pela Ouvidoria Parlamentar c Terceira Secretaria da Câmara dos Deputados, cm Brasilia/DF, cm 04.06.2002 - degravada c revista, aguardando publicação nos Anais correspondentes ao evento). 1988.

60. Antonio de Mattos Ncto. A posse agrária e suas implicaçōes juridicas no Brasil. Bclém: Ccjup, 
agrária. Há um segundo elemento estrutural desta última, a ser considerado e que, ao somar-se ao atributo anteriormente anotado, revela-se como o qualificador desta posse especial, se assim se pode chamá-la, a posse agrária. Trata-se do segundo elemento a constituir o conceito funcional da posse agrária - de caráter genuinamente nacional e originado no período da história de nosso País conhecido como regime de posses elemento este denominado morada habitual. Corresponde àquele locus agrário onde o empreendedor levará a efeito a sua atividade agrária, o seu trabalho produtivo. E são estes, então - trabalho produtivo e morada habitual - os requisitos da distinta e qualificada posse agrária, que difere da posse comum pelo fato da produtividade e da pessoalidade do ato agrário, contagiando-se e impregnando-se da milenar função social da propriedade, pois que desta, aquela é a externalidade, como nos avisa a luminosa lição de Von Ihering.

E é exatamente esta posse - assim qualificada pelos atributos que a integram - a posse hábil à aquisição da propriedade pela via do usucapião. Vale dizer: é, a posse agrária, a posse ad usucapionem capaz de gerar o usucapião especial.

Em 1970, o desembargador Ebert Chamoun - mais tarde um dos notáveis que integrou a comissão de redação do novo Código Civil Brasileiro, sob a coordenação de Miguel Reale - em memorável decisão, ${ }^{61}$ ratificou a posição prioritária acerca da natureza jurídica da posse, registrando que é a posse um estado de fato, um poder de fato que alguém exerce sobre uma coisa e cujo conteúdo é exclusivamente econômico, porque se relaciona com o aproveitamento econômico da coisa, considerada como objeto de satisfação das necessidades humanas. Mas é um estado de fato apenas no sentido de prescindir da existência de um título jurídico: há um direito à proteção da posse sem que a posse esteja fundada em direito.

Se Ebert Chamoun estivesse escrevendo, hoje, o mesmo acórdão, talvez este qualificativo mais contemporâneo e eminentemente social da posse tivesse sido grafado em seu voto, ao lado do adjetivo econômico, albergando melhor em seu seio a completude da funcionalidade social que impregna, assim como a propriedade, o instituto da posse.

Em ensaio de 1987, Rubens Limongi França demonstra que não há um comprometimento estrito entre a proteção possessória acolhida pelo Código Civil,de 1916, e a doutrina de Von Ihering. O professor paulista escreve que nem tudo, e em toda a extensão do que é dito por Von Ihering a respeito da posse, encontra ou deve 
encontrar paralelo absoluto com as nossas prescrições legais. Observe-se, entre outros aspectos que o próprio mestre de Goettingen considera a sua teoria inserta entre as doutrinas relativas, não absoluta, no sentido de que a posse, a seu ver, não se protege em razão de si mesma, senão como forma de proteção do direito de propriedade, que ela exterioriza.Ora, isso não se apresenta como decorrência necessária nos textos legais, especialmente a partir do art. 485 do Código Civil [art. 1.196 do Código Civil atual]. ${ }^{62}$

Rubens Limongi França aplaude a visão de nossos Tribunais ao proteger a posse por si mesma e não como forma de proteção do direito de propriedade. Esta posição se insere nas teorias absolutas sobre posse, assim qualificadas por Von Ihering, e com as quais não-concorda. Essa perspectiva, segundo ele, não estaria em descompasso com a sustentação de Köhler e a sua teoria da destinação social da posse.

Finaliza, Rubens Limongi França, suas reflexões, afirmando que a própria regra de hermenêutica consagrada no art. $5^{\circ}$ da Lei de Introdução ao Código Civil, de 1942, ao mencionar que na aplicação da lei "o juiz atenderá aos fins sociais" bem como "às exigências do bem comum" respalda esse enfoque com larga segurança.

Também trata preciosamente o assunto em comento, isto é, a função social da posse e da propriedade, o civilista Ricardo César Pereira Lira, a quem se atribui os primeiros estudos a respeito do denominado direito favelar, expressivo neologismo por ele criado. ${ }^{63}$ Ele cita a Declaração de Vancouver, enunciada pela Conferência das Nações Unidas sobre Assentamentos Urbanos, em junho de 1976 que propõe que os Estados devem fiscalizar o uso e a propriedade das terras; planejar e administrar a utilização do solo, para que o crescimento dos centros populacionais urbanos e rurais se baseie em plano amplo de utilização do solo. Essas mudanças devem assegurar a realização dos objetivos básicos da reforma social e econômica para cada nação, conforme o seu sistema e as suas leis relativas à propriedade da terra.

62. "As tcorias da posse no Dircito Positivo brasilciro". Posse e propriedade. Coordenador: Yussef Said Cahali. São Paulo: Saraiva, 1987, pp. 663-73.

63. No direito favelar sobressai-sc o direito à laje, bastante utilizado nas favclas do Rio de Janciro. É o dircito de superficic $\mathrm{cm}$ segundo grau, que sc concretiza pelo chamado dircito de sobrclevação. Os moradorcs permitcm que um tercciro construa sobrc sua laje, ficando a cste a possc cxclusiva da moradia por cle cdificada. Curiosamente, como informa Robcrto César Pcrcira Lira, cste dircito de sobrelevação ć similar ao Dircito suiço. Anota que cssa relação de dircito matcrial cxiste entre os favclados como uma realidade. "Como se resolvem os conflitos dela resultante, se na própria comunidade ou pelo dircito formal, ć uma questão de dircito processual que não climina a existência fática, real de um 'dircito de laje"" "A aplicação do Dircito c a lei injusta". Direito \& Justiça. Revista da Faculdade de Dircito da PUC-RS. V. 19, ano XX, 1998, pp. 267-79. Consultem-sc, cspccificamente, p. 274-5. 
Ricardo César Pereira Lira invoca Ruggiero, para quem quanto mais se avança o conceito de solidariedade social, tanto maiores as restrições e vínculos que, no interesse geral e para a utilização social da riqueza, a propriedade está sujeita. Acrescenta, com inspiração em Filomusi, que a propriedade moderna dever ser exercida civilmente, segundo os fins do direito e não se age segundo estes quando, sem qualquer utilidade própria, se exerce o domínio com fins vexatórios. Ele escreve que atualizando essa aguda observação podemos aduzir que, contemporaneamente, a propriedade não sofre apenas as limitações exteriores decorrentes do poder de polícia, consubstanciando a função social da propriedade, mas ela própria é uma função social, sobretudo quando cria poderes inerente a um bem de produção. Nesse caso - prossegue Ricardo César Pereira Lira-a riqueza social aumenta, a distribuição da riqueza se faz mais justamente, na medida em que, visando ao bem de todos, o 'interesse protegido' do dominus definha diante do 'interesse subordinado' $d a$ comunidade. ${ }^{64}$

Segundo o mesmo autor, o direito de propriedade sobre os bens de produção não chega a desaparecer, mas em nome de uma distribuição mais equânime da riqueza social, a soma de poderes remanescentes na titularidade dominial constitui um minimo essencial. A senhoria se comprime, o conteúdo mesmo da propriedade perde em extensão e faculdade por isso que assim determina a justiça social pela vontade de todos. ${ }^{65}$

Os exemplos citados por Ricardo César Pereira Lira são: Lei de Luvas (D. 24.150, de 1934, hoje revogado pela Lei 8.245, de 1991) - renovação compulsória do contrato, por mais 5 anos, para proteção do fundo de comércio; direito de prelação em favor do Poder Público, na alienação de bem tombado (D. 25, de 1937); desapropriação de bens por utilidade pública - D. 3.365, de 1941, por interesse social (Lei n. 4.132, de 1962), por interesse social, de imóveis rurais para fins de reforma agrária (D. 554, de 1969); limitações urbanísticas relativas à altura das edificações; parcelamento ou construção compulsórios, bem como desapropriação; o imposto progressivo para imóveis não-edificados, nos termos do art. $182 \S 44^{\circ}$ da $\mathrm{CF}$ (dependente de lei federal).

O uso e o parcelamento compulsórios serão, na visão de Ricardo César Pereira Lira, instrumentos valiosos em uma politica de repressão à especulação

64. Ricardo César Percira Lira. Elementos de Direito Urbanistico, cit., pp. 313-314. A citação cncontrase na p. 314.

65. Ricarda César Pcrcira Lira. Elementos de Direito Urbanistico, cit., pp. 313-314. 
imobiliária. Como solução para favelas, ele propõe usucapião especial urbano em terras privadas ou públicas. Paralelamente à discriminação de terras públicas, haveria restabelecimento do direito de superfície, concessões de 50 ou 60 anos para população de baixa renda. Entre outros instrumentos hábeis, ele propõe utilizar, também, a concessão de direito real de uso (DL. 271, de 29.03.1971). ${ }^{66}$

5. Direito de Autor: a polêmica acerca de ser um direito especial ou direito de propriedade.

A natureza jurídica do Direito de Autor tem sido debatida há muito. $\mathrm{O}$ assunto foi objeto de rico ensaio de Carlos Alberto Bittar ${ }^{67}$ e de inúmeras lições doutrinárias oferecidas por autoralistas de grande respeitabilidade como Antonio Chaves. ${ }^{68}$

A evolução histórica do Direito Autoral e seu caminhar em direção à autonomia científica foram cuidadosamente tratados por Carlos Alberto Bittar. Considerase que o primeiro texto legal acerca de direitos autorais foi o Copyright Act, da Rainha Ana, da Inglaterra, em 1710, conhecido exatamente como Estatuto da Rainha Ana.

Em 1793, duas leis francesas foram editadas: uma sobre execução e reprodução de obras dramáticas e escritas, composições musicais, pintura e desenhos; outra sobre direito de exclusividade aos criadores, como direito do autor e não do editor, conforme ocorria na Idade Média.

Em 1761, o advogado Héricourt obtém decisões favoráveis aos herdeiros de La Fontaine e de Fenelon (1777), na ocasião em que estiveram em confronto com os editores.

A importância do Arrêt Rose Bonheur, de 1865, é enfatizada por Carlos Alberto Bittar, pois neste julgado foi reconhecida pela primeira vez, a primazia ou preponderância do direito imaterial (Direito de Autor) em relação ao Direito Obrigacional. O pintor não foi obrigado a entregar o quadro encomendado por terceiro, em razão de ter mudado de concepção artística.

Em 1886 advém a Convenção de Berna, revista em 1908, em Berlim, na qual foram incluidos os direitos morais de autor, graças ao advogado Hervieu. Com a

66. Ricardo César Pcreira Lira. Elementos de Direito Urbanistico, cit., p. 363.

67. Carlos Alberto Bittar. "Autonomia Científica do Dircito de Autor". Revista da Faculdade de Dircito da Universidade de São Paulo, v. 87, p. 98.

68. Antonio Chaves. Direito de Autor. Principios fundamentais. Forense: Rio de Janciro, 1887, pp. 3-16. 
vertente dos direitos morais, direitos da personalidade, começa a delinear-se a especialidade do direito autoral.

Na revisão de Roma, em 1928, Eduardo Piola Caselli debateu com o alemão oll, em polêmica famosa, firmando afinal a tese da incindibilidade ou unicidade do Direito de Autor, agregando-se direitos morais e patrimonais e enfatizando-lhe a especialidade. Segundo Carlos Alberto Bittar, esta polêmica entre Zoll e Piola Caselli, foi chamada de $O$ Debate do Século e a sufragação da tese possibilitou o reconhecimento da autonomia científica do Direito de Autor, que passou a figurar em legislação especial, inclusive no Brasil (Lei n. 496, de $1^{\circ}$ de agosto de 1898). Antes, a Lei de Fundação dos Cursos Jurídicos, de 11 de agosto de 1827 , no art. $7^{\circ}$ já previa o direito de autor do professor sobre suas aulas.

O Código Civil, de 1916, contemplou expressamente a propriedade literária, artística e científica, nos arts. 649 a 673.

A Lei n. 5.988, de 14.12.1973 - cujo autor foi José Carlos Moreira Alves, então consultor geral da República - tendo regulado inteiramente a matéria, revogou o Código Civil e já inovou na terminologia, abandonando o termo propriedade literária, artistica e cientifica, por Direito Autoral abrangendo não-só os criadores como os titulares dos denominados direitos conexos, relativos a artistas, intérpretes e executantes. A lei de direitos autorais alcançou depois o direito de arena, hoje expurgado de seu âmbito e consagrado em lei especial. ${ }^{69}$

Esta lei de 1973 foi recentemente revogada pela Lei n. 9.610, de 19 de fevereiro de 1998, que lhe segue as mesmas diretrizes, em essência.

Embora haja doutrinas diversas que procuram explicar a natureza jurídica do Direito de Autor, a predominante desvincula-o do direito de propriedade material. $\mathrm{Na}$ falta de uma denominação mais precisa, cai-se na classificação comum de direito especial ou direito sui generis.

Conforme adverte Antonio Chaves a diferença essencial entre o Direito de Autor e o direito de propriedade material, se funda tanto pelo modo de aquisição originário - tendo como único título, a criação da obra - quanto pelos modos de aquisição derivados. Enfatiza, louvando-se em Bluntschli que no direito autoral não há uma transferência perfeita, já que a obra intelectual não sai completamente do âmbito de influência da personalidade que a criou. Distingue-se, ainda, quanto à duração, à extensão, posse, comunhão, forma de extinção.

69. Sobre dircito de autor, $\mathrm{c}$ dircito de arena consultc-se "Dircito de arena, dircito de autor c dircito à imagem", de Silmara Juny Chinclato. In: Estudos de Direito de Autor, Direito da personalidade, Direito do Consumidor e danos morais. Homenagem ao Professor Carlos Alberto Bittar. Silmara Juny Chinelato c Eduardo Carlos Bianca Bittar, coordenadores. Rio de Janciro: Forense Universitária, 2002, pp. 3-24. 
Escreve Antonio Chaves que: no que, porém, mais se distancia o direito autoral da propriedade material é na separação perfeitamente nitida que se estabelece no periodo anterior e posterior à publicação da obra, sendo absoluto, na primeira, $e$ constituindo-se, na segunda, de faculdades relativas, limitadas e determinadas: patrimoniais exclusivas de publicação, reprodução etc, que recaem sobre algumas formas de aproveitamento econômico da obra, e de natureza pessoal, referentes $\grave{a}$ defesa da paternidade e da integridade intelectual da obra. Direito especial, como se revela, exige, por isso mesmo, uma regulamentação especifica, incompativel com o caráter demasiadamente amplo e genérico dos direitos da personalidade, assim como com os estreitos limites da propriedade material ou patrimonial. ${ }^{70}$

A discussão sobre a natureza jurídica do Direito de Autor é de fundamental importância, pois repercutirá em temas diversos em relação aos quais as polêmicas, dúvidas, indagações e perplexidades serão resolvidas à luz da tomada de posição quanto à natureza em tela.

Assim, por exemplo, quanto à prescrição de direito autoral, assunto que tem suscitado polêmica entre autores e que, no nosso modo de ver, não pode ser resolvido, de modo singelo, pela aplicação da regra relativa ao direito de propriedade material. O mesmo se diga quanto à desapropriação de direito autoral, merecendo ambos os temas estudo específico. ${ }^{71}$

A autonomia científica do Direito de Autor é bem demonstrada por Carlos Alberto Bittar, em ensaio de igual título, que reproduz aula proferida no concurso para professor titular de Direito de Autor na Faculdade de Direito da Universidade de São Paulo. O autor demonstra, de modo convincente, que tem o Direito de Autor as características que sustentam a autonomia científica de um ramo do Direito, aplicando as lições de Alfredo Rocco (Principii di Diritto Commerciale, p. 161): são quatro os requisitos para autonomia científica de um ramo do Direito: objeto, principios especificos, normas especiais e conceitos e figuras próprias.

Como objeto próprio lembra ser ele a regulamentação juridica da criação e da utilização econômica de obras de engenho (criações intelectuais artísticas e cientificas, inclusive software).

70. Direito de Autor. Principios fundamentais. Rio de Janciro: Forensc, 1987, p. 16.

71. Nem sc argumente que o Dircito de Autor é, para cfeitos Icgais, bem móvel, scgundo art. $3^{\circ} \mathrm{da}$ Lci n. 9.610/98. Essa considcração não o descaracteriza como dircito especial, cuja vertente de dircito de personalidade distancia-o do dircito de propriedade matcrial. O Código Civil de 2002 não repetc o disposto no inciso $\mathrm{lll}$ do art. 48, scgundo o qual consideram-sc móvcis para os cfcitos legais, os dircitos de autor. Em mclhor redação dispõc, no inciso III do art. 83, que se consideram móvcis para os cfcitos legais, "os direitos pessoais de caráter patrimonial e respectivas ações". Ai sc incluem os dircitos patrimoniais de autor. 
Entre os principios especiais invoca: limitação, no tempo, de direitos patrimoniais e vitaliciedade dos direitos morais, direitos da personalidade, enfatizando a natureza híbrida do Direito de Autor.

A nós parece relevante que o brocardo jurídico "mors omnia solvit" não se aplique ao Direito Autoral que, em uma de suas vertentes, tem a natureza jurídica de direito da personalidade. Os direitos morais de autor ultrapassam-lhe a vida e jamais prescrevem. Elencados, de modo exemplificativo, no art. 24 da Lei n. 9.610, de 1998, são reconhecidos ao autor morto, para sempre. Entre eles, avulta o direito de paternidade por meio do qual o autor será sempre considerado o criador da obra, mesmo quando caída em domínio público, e a qualquer tempo.

A exclusividade de exploração da obra, pelo autor, encontra fundamento na Constituição Federal, no inciso XXVII do art. $5^{\circ}$, sendo excepcional a desapropriação de Direito de Autor, que não segue as mesmas regras da propriedade material.

Acresça-se a interpretação especial que o norteia, de acordo com o art. $3^{\circ}$ da Lei 5988/73 e art. $4 .^{\circ}$ da Lei n. 9.610/98. Segundo ela, são interpretados restritivamente, em favor do autor, os regócios jurídicos.

$\mathrm{O}$ terceiro requisito refere-se a Leis especiais e normas especiais, requisito presente tanto pela existência de lei especial, bem como de normas especiais nas leis sobre telecomunicações em geral.

Quanto a conceitos e institutos peculiares, verifica-se a especificidade do conceito de autor, titular originário e derivado - por sucessão, por via contratual bem como de obras originária e derivada. Lembra, entre outros, a limitação ao exercício dos direitos, prevista no art. 49 da Lei revogada e no art. 46 da atual.

A vasta literatura estrangeira - européia e latino-americana, inclusive brasileira - demonstra que a doutrina trata o Direito de Autor como direito especial não-identificado com o direito de propriedade.

Registre-se, por derradeiro, a importância crescente do Direito de Autor, oriunda das novas formas de criação e novas formas de utilização das obras, na pósmoderna era da comunicação, na qual os respectivos meios se multiplicam, se aperfeiçoam e se popularizam: a quarta era dos direitos, na visão de Norberto Bobbio. ${ }^{72}$

São Paulo, março de 2003

72. Norbcrto Bobbio. A quarta era dos direitos. Rio de Janciro: Editora Campus, 1997. Frisc-se que cssa cra ć a cra da comunicação c da Biogenćtica. 
Bibliografia

AMARAL, Francisco. "A autonomia privada como princípio fundamental da ordem jurídica. Perspectivas estrutural e funcional". Estudos em homenagem ao Prof. Doutor António Ferrer Correia, v. II. Boletim da Faculdade de Direito. Universidade de Coimbra, número especial, Coimbra, 1989, pp. 5-41.

BITTAR, Carlos Alberto. "Autonomia científica do direito de autor". Revista da Faculdade de Direito da Universidade de São Paulo. v. 89: 87-98, 1994.

_. "Os Direitos Reais na Constituição de 1988". A Propriedade e os Direitos Reais na Constituição de 1988. (coord. Carlos Alberto Bittar). São Paulo: Saraiva, 1991, pp. 1-13.

BOBBIO, Norberto. A Era dos Direitos. trad. Carlos Nelson Coutinho. Rio de Janeiro: Ed. Campus, 1992.

CHAVES, Antonio. Direito de Autor. Principios fundamentais. Rio de Janeiro: Forense, 1987.

CHINELATO, Silmara Juny de Abreu. "Direito de arena, direito de autor e direito à imagem". Estudos de Direito de Autor, Direito da Personalidade, Direito do Consumidor e danos morais. Homenagem ao Professor Carlos Alberto Bittar. Silmara Juny Chinelato e Eduardo Carlos Bianca Bittar, coordenadores. Rio de Janeiro: Forense Universitária, pp. 3-24, 2002.

Do nome da mulher casada: Direito de Familia e Direitos da Personalidade. Rio de Janeiro: Forense Universitária, 2001.

DI PIETRO. Maria Sylvia Zanella. Do Direito Privado na Administração Pública. São Paulo: Atlas, 1989.

DI PORTO, Andrea. "O papel do cidadão na tutela do ambiente" Trabalho apresentado no VI Congresso Latino-Americano de Direito Romano, Civil e Comparado, realizado em 1990, no Rio de Janeiro. Estudos Juridicos. São Leopoldo. v. 23. n. 59. pp. 79-83. Set/dez/1990.

FACHIN, Luiz Edson. "A Cidade Nuclear e o Direito Periférico (reflexões sobre a propriedade urbana)". Revista dos Tribunais, 1996, v. 743: 107-110.

. Função Social da Posse e da Propriedade Contemporânea. Porto Alegre: Sergio Antonio Fabris Editor, 1988.

GIORGIANNI, Michele. “O Direito Privado e as suas atuais fronteiras”. Revista dos Tribunais. v. 747:35 e ss.

GISCHKOW, Emílio. Princípios de Direito Agrário. São Paulo: Saraiva, 1988. GOMES, Orlando. A crise do Direito. São Paulo: Ed. Max Limonad, 1955. 
HIRONAKA, Giselda M. Fernandes Novaes. "Função Social do Contrato" Direito Civil-Estudos. Belo Horizonte: Del Rey, 2000, pp. 101-117.

. "Enfiteuse" Direito Civil - Estudos. Belo Horizonte: Del Rey, 2000, pp. 185-193.

“Usucapião Especial: características do imóvel usucapiendo em face da Constituição Federal de 1988”, Direito Civil-Estudos. Belo Horizonte: Del Rey, 2000, pp. 195-198.

. "Contrato: estrutura milenar de fundação do direito privado. Superando a crise e renovando princípios, no início do vigésimo primeiro século, ao tempo da transição legislativa civil brasileira", Revista do Advogado - Novo Código Civil Aspectos Relevantes, Associação dos Advogados de São Paulo, ano XXII, n. 68, dezembro/2002, pp. 79-86.

JAYME, Erik. "Identité culturelle et integration: le droit international privé postmoderne" Cours général de droit international privé. Recueil des Cours. Haye. $\mathrm{n}$. 251.pp. 9-268. 1995.

JUNQUEIRA DE AZEVEDO, Antonio. "O Direito pós-moderno e a codificação" Revista da Faculdade de Direito da Universidade de São Paulo, v. 94, pp. 3-11, 1999.

O Direito dos Contratos e o novo Código Civil Brasileiro, palestra proferida no I Seminário sobre o Novo Código Civil Brasileiro: o que muda na vida do cidadão, promovido pela Ouvidoria Parlamentar e Terceira Secretaria da Câmara dos Deputados, em Brasília (DF), em 04.06.2002 (degravada e revista, aguardando publicação nos Anais correspondentes ao evento).

. Entrevista ao jornal Tribuna do Direito, março de 1998, p. 19.

LIMONGI FRANÇA, RUBENS. "As teorias da posse no Direito Positivo brasileiro". Posse e propriedade. Yussef Said Cahali, coordenador. São Paulo: Saraiva, pp. 663-73, 1987.

LIRA, RICARDO CÉSAR PEREIRA. Elementos de Direito Urbanistico. Rio de Janeiro: Renovar, 1997.

. "A aplicação do Direito e a lei injusta". Direito \& Justiça. Revista da Faculdade de Direito da PUC-RS. Volume 19, ano XX, pp. 267-79, 1998.

MADEIRA, Hélcio Maciel. Digesto de Justiniano. Livro I, $2^{\mathrm{a}}$ ed. São Paulo: RT, 2000.

MALUF, Carlos Alberto Dabus. Limitações ao Direito de Propriedade. São Paulo: Editora Saraiva, 1997. 
MATTOS NETO, Antonio de. A posse agrária e suas implicações juridicas no Brasil. Belém: Cejup, 1988.

MEDAUAR, Odete; ALMEIDA, Fernando Dias Menezes, coordenadores. Estatuto da Cidade. Lei n. 10.257, de 10.07.2001. São Paulo: RT, 2002.

MOREIRA ALVES, José Carlos. Direito Romano, v. I. 10" ed. Rio de Janeiro: Forense, 1995.

. "A detenção no Direito Civil brasileiro" Posse e propriedade, coordenação de Yussef Said Cahali, São Paulo: Saraiva, pp. 1-31, 1987.

PEREIRA, Caio Mário da Silva. Direito Civil-alguns aspectos de sua evolução. Rio de Janeiro: Editora Forense, 2001.

SILVA, Clóvis do Couto e. "O Direito Civil brasileiro em perspectiva histórica e visão de futuro" O Direito privado brasileiro na visão de Clóvis do Couto e Silva. Vera Maria Jacob de Fradera, coordenadora. Porto Alegre: Livraria do Advogado Editora, 1997.

. "O Direito Civil brasileiro em perspectiva histórica e visão de futuro" Revista dos Tribunais, n. 628, 1988.

TEPEDINO, Gustavo. "Contornos constitucionais da propriedade privada" Temas de Direito Civil, Rio de Janeiro: Renovar, pp.267-92, 1999.

“A nova propriedade (o seu conteúdo mínimo entre o Código Civil, a legislação ordinária, e a Constituição)”. Revista Forense, v. 306, pp. 73-8.

. "Aspectos da propriedade privada na ordem constitucional" Estudos Juridicos. (coord. James Tubenchlak e Ricardo Bustamante). Rio de Janeiro: 1991.

VIANA, Rui Geraldo Camargo. Direitos Reais e o novo Código Civil Brasileiro, palestra proferida no I Seminário sobre o Novo Código Civil Brasileiro: o que muda na vida do cidadão, promovido pela Ouvidoria Parlamentar e Terceira Secretaria da Câmara dos Deputados, em Brasília (DF), em 05.11.2002 (degravada e revista, aguardando publicação nos Anais correspondentes ao evento).

VILLAÇA AZEVEDO, Álvaro. Verbete liberdade contratual, Enciclopédia Saraiva do Direito 49/370-371, São Paulo: Saraiva, 1977. 